\title{
THE PRESIDENTIAL SYSTEM WITH A MULTIPARTY SYSTEM IS BASED ON THE 1945 CONSTITUTION OF THE REPUBLIC OF INDONESIA
}

\author{
Nur Afti Aulia ${ }^{1 *}$, La Ode Husen², Agussalim A. Gadjong ${ }^{3}$ \\ ${ }^{1}$ Student of Master of Law Science Program, Universitas Muslim Indonesia, Makassar \\ ${ }^{2}$ Professor of the Faculty of Law, Universitas Muslim Indonesia, Makassar \\ ${ }^{3}$ Lecturer of the Faculty of Law, Universitas Muslim Indonesia, Makassar \\ *Correspondence Author: Nur Afti Aulia \\ Email Correspondence: na.aulia01@gmail.com
}

\begin{abstract}
Coalitions of political parties built within the presidential system, especially in Indonesia, are non-binding and permanent. If government policies or programs are not famous or inline, political parties tend to engage in opposition. This study aims to determine the implementation of the presidential system with a multiparty system and efforts to realize a stable and dynamic government based on the Indonesian constitutional system. This research uses a normative approach. Types and sources of legal materials consist of primary legal materials, secondary legal materials, and tertiary legal materials. The analysis technique used in this research is the hermeneutic analysis method. The study results concluded that with the implementation of the presidential system with a multiparty system, it is rare for a President to be elected and from the majority party. Furthermore, with the election of a minority President and a majority in Parliament, the President will strengthen his position by forming a coalition. However, building a stable coalition is difficult in a multiparty presidential democracy. In this regard, the institutional engineering agenda that needs to be designed includes simplifying the number of factions in Parliament by tightening the threshold requirements for fraction formation; parliamentary coalition regulations aimed at both political blocs (coalition and opposition); strengthening the institution and authority of the Regional Representative Council to balance the House of Representatives so that checks and balances not only occur between the President and the House of Representatives but also between the House of Representatives and the Regional Representative Council.
\end{abstract}

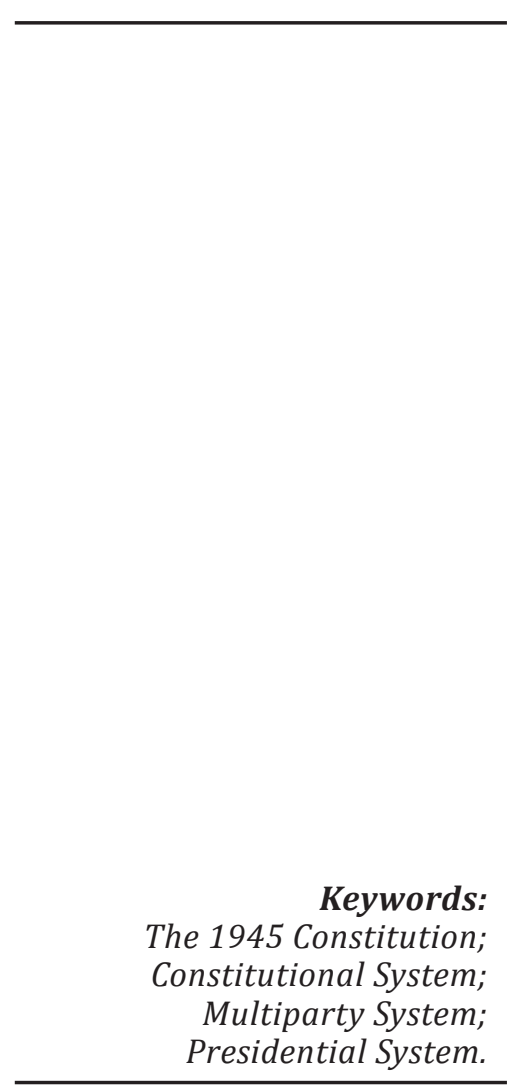

Articles with open access under a CC BY SA-4.0 license

\section{INTRODUCTION}

Indonesia as a democratic law state is emphasized in Article 1 section (3) of the 1945 Constitution of the Republic of Indonesia (hereinafter referred to as the 1945 Constitution), which regulates that "Indonesia is a law-based state" which was enacted 
on November 9, 2001. A formula like this is also contained in The 1949 Provisional Constitution of the Republic of the United States of Indonesia and The 1950 Provisional Constitution of the Republic of Indonesia (Asshiddiqie, J., 2003).

Implementing a democratic system is holding direct general elections, as based on Article 22E section (1) of the 1945 Constitution, which mandates quality general elections. Besides, the broadest possible public participation based on the principles of democracy, namely direct, general, free, confidential, honest and fair through laws and regulations (Handayani, Y., 2014).

The election places the people as the main point who holds primary sovereignty, according to J. J. Rousseau in Librayanto, R. (2009), the people are not the sum of individuals in the state but are a unit formed by these individuals and have the will to acquire this sovereignty through the agreement of the community. Furthermore, according to J. J. Rousseau, the community agreement is called the "volonte generale", or which is considered to reflect the general will. Because if what is meant by the people is the sum of the individuals in the country and not a single unit formed, then the will in it is not volonte generale but "volonte de tous".

The constitution regulates the general election of the President and Vice-President. In this case, the presidential system is an essential part of the direction of the President and the Vice-President elections series. The presidential government system requires the President as head of state and head of government to have a strong position in government so that President programs can be carried out correctly.

Based on Article 22E of the 1945 Constitution, the President and the Vice-President Election and the Legislative Election were introduced. The level of direct election is the obligation of the people to be elected. The tiered direct election becomes the agenda for the General Election to be held within five years of implementation in Indonesia.

According to Article 6A of the 1945 Constitution, the President and the Vice-President nominations can only be carried out by political parties or coalitions of political parties. Thus an independent cannot nominate. Based on Law of the Republic of Indonesia Number 2 of 2008 on the Political Party in question are political parties that have fulfilled administrative verification and factual verification and have passed as eligible participants (D., M. M. M., 2010).

In reality, presidential and multiparty systems are less successful in creating an effective and stable government than parliamentary systems. In a presidential and multiparty system, building coalitions of political parties to win elections is a very natural and common thing. Coalitions of political parties built within the presidential system, especially in Indonesia, are non-binding and permanent. If government policies or programs are not famous or inline, political parties tend to engage in opposition or resistance. 
Presidential and Legislative elections are held separately. The elected President may be the President who does not get majority support in the parliament. In the presidential system, parliamentary support to the President is very influential in making laws and implementing government programs and policies (Partono, P., 2008).

There have been many studies in Indonesia that discuss Presidential and Multiparty Systems based on the 1945 Constitution, either partially or as a whole, including the following.

Arman, Z. (2018) concluded that:

"The Presidential system can be considered less suitable to be applied in a multiparty system. However, because the Indonesian nation has entered into an era of democratization that guarantees freedom of association which can no longer be stopped, the number of parties is no longer limited as in the New Order era. Therefore, there is a need for a regulatory mechanism that causes the number of political parties to shrink without any restrictions or restrictions naturally."

Hamudy, M. I. A. \& Rifki, M. S. (2019) concluded that:

"The presidential government system in Indonesia has not shown optimal strengthening because it is faced with a multiparty system. The legitimacy of the elected President, who should be the President's political capital, is often paralyzed when faced with the political process at the elite party level in the parliament. Efforts to build political coalitions cannot be avoided. However, the coalition that has been built so far tends to be pragmatic and more as a transactional politic than political development. Admittedly, it is not easy to implement a presidential government system because it must face an extreme multiparty system."

Wiyono, S., et al. (2020) concluded that:

"When examined, the Republic of Indonesia's constitutional system, based on the 1945 Constitution, is characteristically Indonesian. The free multi-party system's impact is that no party will gain a dominant seat in the parliament in every legislative general election. Therefore, the formation of a presidential cabinet cannot be done without forming a coalition with other parties. The formation of a cabinet through a coalition will weaken the professionalism of the ministers in the cabinet. The ministers appointed by their parties are often very unprofessional since they have no expertise in the fields related to their ministerial authority. Therefore, it is time for the elected President to act decisively when appointing ministers as their assistants. $70 \%$ of the ministers should be professionals, and 30\% are from representatives from the supporting parties. When this is done, the cabinet will run well, and there will be fewer interventions by the parties. The President should not make laws that will constrict themselves, undermining the authority granted to them by the 1945 Constitution. Ironically, the President must first ask the DPR's consideration when appointing Military Commander and Chief of the Police. The prevailing Laws regulating those above should be abolished, and the President should not approve any Draft Laws and Regulations that work similarly. On the other hand, the future Parliamentary threshold needs to be 
continuously increased until the number of parties is smaller, and a simple multi-party system is achieved."

From some of the descriptions above, it can be understood that previous research has focused on the linkage of presidential systems and multiparty systems. Meanwhile, this research focuses on implementing aspects of the House of Representatives' rights as representatives of political parties with a multiparty system. Furthermore, this right is related to the President's presence in the presidential system. Therefore, this study has differences from previous studies.

Based on the description above, this study aims to determine the implementation of the presidential system with a multiparty system and efforts to realize a stable and dynamic government based on the Indonesian constitutional system. It is hoped that the results of this study can provide benefits to political elites so that they can realize stability and productive conflict in the presidential system with a multiparty system based on the Indonesian constitutional system.

\section{METHOD}

This research uses a normative approach, which examines the law in the sense of laws and regulations and includes a broader aspect, namely something that can be traced through various references (Qamar, N. \& Rezah, F. S., 2020). This approach is also known as the literature approach, which means studying books, laws, regulations, and other documents related to this research (Fitrah, F. A., 2021). Types and sources of legal materials consist of:

1. Primary legal materials, namely legal materials derived from laws and regulations, official records, minutes of the making of statutory regulations, and judges' decisions (Yafid, B. M. \& Muzakkir, A. K., 2020). The primary legal material used in this research is the 1945 Constitution of the Republic of Indonesia.

2. Secondary legal materials, namely legal materials sourced from reference books and scientific articles related to this research.

3. Tertiary legal materials, namely legal materials sourced from legal dictionaries, papers, or data found on the internet related to this research.

The data collection technique used in this research is a literature study, namely inventorying, reading, and analyzing legal materials, both primary, secondary, and tertiary legal materials (Suhyana, F. A., Suseno, S., \& Ramli, T. S., 2021). The analysis technique used in this research is the hermeneutic analysis method, which is used to understand the text as a series of signs, which is then described in a certain way by the author (Bachmid, F., 2021). 


\section{RESULTS AND DISCUSSION}

\section{A. Theoretical Framework}

\section{Rule of Law Theory}

In the Indonesian literature, the translation of the rule of law from the Dutch term "rechtsstaat", although countries in Continental Europe use different terms concerning "rule of law". In France, for example, using the term "etat de droit". Meanwhile, in Germany and the Netherlands, the same term is used, namely "rechtsstaat". The two terms used in Continental Europe are terms that are different from the British legal system, although the expressions "legal state" or "state according to law" or "the rule of law" try to express an idea that is the same (Notohamidjojo, 0., 1970).

According to Azhary, M. T. (2009), stated that:

"Plato's writing initiated the idea of the rule of law on "nomoi". Then developed the concept of rechtsstaat, the rule of law, socialist legality, the constitutional state of Pancasila, and Islamic nomocracy."

Another concept concerning rechtsstaat is legality or etat de droit in the Continental European legal system. Meanwhile, the term the rule of law became famous after Albert Venn Dicey's work entitled "Introduction to Study of the Law of the Constitution” was published in 1885 (Husen, L. O., 2019).

Historically, the emergence of the terms rechtsstaat and the rule of law was born from a different legal system background, as according to Hadjon, P. M. (1998), that:

"The term rechtsstaat was born as a reaction against absolutism because it is revolutionary and rests on a continental legal system called civil law. It is different in understanding the rule of law, whose development occurs evolutionarily, and rests on the common law understanding or system of law."

However, in its development, the difference in the background need not be contested because it leads to the same goal, namely the aim of realizing the protection of human rights.

\section{Democracy Theory}

Democracy has an essential meaning for the people who use it because democracy is the right of the people to determine for themselves the way of life of a country's organization. The term democracy comes from Greece, Demos (people) and Kratos (power). The term democracy has been known since the $5^{\text {th }}$ century BC, which was initially a reaction to the dictatorships in the Ancient Greek countries (Abdillah, M., 1999). While Democracy in Webster's Dictionary is defined as (Gove, P. B., 1993; Puspa, Y. P., 1997): 
"A government in which the supreme power is vested in the people and exercised by them directly or indirectly through a system of representation usually involving periodically held free elections."

As for the definition of democracy according to Mayo, H. B. (1960), that:

"A democratic political system is one in which public policies are made on a majority basis, by representatives subject to effective popular control at periodic elections which are conducted on the principle of political equality and under conditions of political freedom."

In this connection, freedom and democracy are often used mutually, but they are not the same thing. Democracy is a set of ideas and principles about freedom. However, it also includes a set of practices and procedures that have been shaped through a long and often tortuous history. In essence, democracy is the institutionalization of freedom (Malian, S., 2001). Democracy as the basis of state life implies that at the last level, the people provide provisions in essential matters relating to their lives, including assessing state policies, because these policies determine the lives of the people (D., M. M. M., 2000).

The founding fathers' ability to formulating democracy in the 1945 Constitution is not only influenced by their educational background and knowledge. However, family life and areas of origin are entrenched in all corners of the country of Indonesia. The 1945 Constitution was passed on August 18, 1945, but its birth process went through a very democratic preparation. It can be seen from the formulation in the Preamble to the 1945 Constitution, which is very brief but has laid the foundation for a modern democratic legal state which is defined as a legal democracy (constitutional democracy) (Asshiddiqie, J., 2001).

The affirmation of the state of Indonesia as a democracy (people's sovereignty) as based on Article 1 section (2) of the 1945 Constitution, regulates that "Sovereignty is in the hands of the people and is implemented according to this Constitution". The Founding Fathers established this idea of democracy with the formulation that within six months after the end of the Greater East Asian War, the President of Indonesia regulated and carried out all matters stipulated in the Constitution.

The description above shows that in the Indonesian context, democracy has three meanings, namely:

a. Democracy is associated with the government system regarding how people are involved in government administration;

b. Democracy is a principle that is influenced by the culture and history of the Indonesian nation so that the term constitutional democracy appears; and

c. Democracy is a tentative solution to solve some of the problems faced in the constitutional context so that the term deliberation and consensus were born. 


\section{Power Separation Theory}

In the constitution and the practice of power in various countries, it is known as the concept of "separation of powers" and "division of power". Therefore, according to Marshall, G. (1971), states that:

"The phrase 'separation of powers' is 'one of the most confusing in the vocabulary of political and constitutional thought'. The phrase has been used 'with varying implication' by historians and political scientists, this is because the concept manifests itself in so many ways."

The term "separation of powers" or "division of power" is used when the separation of powers is applied concretely in a country (Husen, L. 0., 2005). The theory of separation of powers gives rise to various definitions in various constitutional laws, such as understanding the system of checks and balances, independence of judicial power, the delegation of legislative powers, executive responsibility to the judicial review bodies, and various other definitions. Therefore, various modifications emerged (Husen, L. O., 2005).

Locke, J. (1967) distinguishes four functions of the state: the formation of laws (legislating), making decisions (judging), using internal power in implementing laws and using these forces outside the country to defend society. Locke called the first function called legislative power, the second function called executive power, and the third function called federative power, which included war and peace involving foreign powers (Husen, L. O., 2019).

Besides, Montesquieu, B. d. (2011) also put forward the theory of separation of state powers and categorized them into three powers, namely:

a. Legislative Power;

b. Executive Power; and

c. Judicative Power.

Suny, I. (1985) concluded that:

"The separation of powers in the material sense does not exist and has never been implemented in Indonesia. What exists and is implemented is the separation of powers in the formal sense."

It shows that in Indonesia, there is a division of power and not a separation of powers.

The 1945 Constitution of the Republic of Indonesia divides into several separate articles relating to the distribution of power without emphasizing the separation. However, it cannot be denied that the teachings of trias politica have inspired the distribution of power stipulated in the 1945 Constitution. Because in the systematics of the 1945 Constitution, it states Chapter III on the Executive Power, Chapter VII on the House of Representatives, and Chapter IX on Judicial Powers. Such systematics was supported by an understanding of the constitutional 
teachings that developed at that time, even though the 1945 Constitution did not explicitly separate the three powers as Montesquieu wanted. By Jennings, S. W. I. (1963) theory, the 1945 Constitution recognizes the separation of powers in a formal sense. Therefore the separation of powers is not maintained in a principal sense. In other words, the 1945 Constitution only recognizes the distribution of power, not the separation of powers. In a constitutional state where it is essential to have a trias politica or not, the problem is can the tools of the state's power be avoided from tyrannical practices (Suny, I., 2000).

\section{B. The Presidential System with a Multiparty System is Based on the Indonesian Constitutional System}

The 1945 Constitution does not explicitly state that Indonesia adheres to a presidential system. However, if you carefully read the provisions in several articles in the 1945 Constitution itself, it will appear that Indonesia adheres to a presidential system of government. ${ }^{1}$

Indonesia applies a presidential system with a multiparty system. Based on Mainwaring, S. (1993) study, that:

"It is rare for a President to be elected and from the majority party. With the election of a minority President and a majority in Parliament, the President will strengthen his position by forming a coalition."

However, building a stable coalition is difficult in a multiparty presidential democracy. The reason is that the coalition built has no legal attachment so that political parties can dissolve the coalition in the presidential system (Efriza, E., 2018).

Linz, J. J. (1994) even said that:

"The separation of powers between the executive and legislative bodies in the presidential system tends to cause polarization and political instability, so that it is considered not very suitable for adoption in new democracies."

The potential problems of the presidential democratic system in post-New Order Indonesia were expected when the accelerated electrons in the 1999 elections were designed based on a proportional representation system on the one hand and a multiparty system on the other. As is well known, the proportional system adopted in the 1999 elections resulted in a multiparty system with a high degree of fragmentation and polarization and a map of the strength of the House of Representatives with a similar tendency. As is well known, not a single political party

\footnotetext{
${ }^{1}$ Reynolds, A., Reily, B., \& Ellis, A. (2016) explained that the presidential system, in general, has three characteristics: First, The President is elected for a predetermined period and is responsible to the Constitution, not to the legislative body. Besides, the President cannot be demoted halfway by a motion of no confidence in the legislature but only by the impeachment process because he has violated the Constitution or violated the oath of office; Second, The President is elected in general, either directly by the people or through an electoral body (electoral college, as is the case in the United States). Meanwhile, the Prime Minister is elected by the legislative body; Third, The President is the sole chief executive, while the parliamentary cabinet is the collective executive.
} 
has succeeded in becoming the majority power in the House of Representatives. A total of 21 parties won seats in the House of Representatives -grouped into ten factions- while the Indonesian Democratic Party of Struggle, which won the legislative elections, only won 153 seats out of 500 House of Representatives seats.

The political constellation in parliament remained relatively unchanged in the 2004 elections, although institutional breakthroughs have been made by applying the electoral threshold. In the second post-New Order election, 16 influential parties were produced without a majority power in the House of Representatives (out of 24 election participants) and again grouped into ten factions. The Party of the Functional Groups, which won the legislative elections, only managed to win 127 seats out of 550 seats in the House of Representatives.

The reality of the political configuration without a majority power in the House of Representatives is one of the crucial factors behind forming the "rainbow" coalition cabinets, both the National Unity Cabinet under President Abdurrahman Wahid, the Gotong Royong Cabinet under President Megawati Sukarnoputri, and the United Indonesia Cabinet under President Susilo Bambang Yudhoyono. As is well known, Indonesia's post-New Order presidents were actually "minority presidents" (minority presidents). ${ }^{2}$ In the sense that the elected president (either by the MPR or directly by the people) having a relatively small political base does not achieve simple majority support in parliament. Although President Megawati Sukarnoputri comes from the Indonesian Democratic Party of Struggle, which won the legislative elections in 1999, the number of seats for the party led by President Megawati Sukarnoputri is only 153 House of Representatives seats, less than half plus one parliamentary seat.

President Joko Widodo and Vice-President Jusuf Kalla's administration in 20142019, Indonesia continued to run a presidential system in conjunction with a multiparty system. It could even be said to be extreme multiparty because of the large number of political parties. This has led to the Joko Widodo-Jusuf Kalla pair's dependence on the coalition party's opinion and causing various other problems. Many political observers even said that this era was the era of "parliamentary presidential taste".

It is also proven by several authors discussing the topic of the presidential system and its relation to the multiparty system in Indonesia, especially in the Joko Widodo-Jusuf Kalla era. Combining the presidential and multiparty systems and the way President Joko Widodo manages the government is managing a "fat" coalition with accommodative and transactional leadership. The nature of this management is an effort to maintain a harmonious relationship between the

${ }^{2}$ As for the minority president and its impact on presidential, for example, the concept of "minority presidents", where Cheibub, J. A. (2002) describes a situation where the President cannot control more than $50 \%$ of parliamentary support. 
President and the House of Representatives with the consequence that President Joko Widodo violates his commitment to creating an unconditional coalition and does not share seats in power (Efriza, E., 2018). The problems that arise with the combination of the presidential and multiparty systems in the reform era have caused political and government instability, including (Wibisono, Y., 2017):

1. The issue of cabinet formation and reshuffling;

2. The weak coalition of parties supporting the government;

3. The size of the coalition structure;

4. The threat of impeachment;

5. Weakened presidential prerogatives;

6. Political factors as a consideration in policymaking;

7. The dual loyalty of ministers from political parties;

8. Disharmony in the relationship between the President and the Vice-President;

9. The weak character of the national leadership.

Table 1. The Proposed Use of the House of Representatives Interpellation Rights (1999-2019)

\begin{tabular}{|c|c|c|c|c|}
\hline Period & Date & Interpellation Material & Proposer Elements & $\begin{array}{l}\text { Proposal } \\
\text { Status }\end{array}$ \\
\hline \multirow[t]{2}{*}{$\begin{array}{l}\text { President } \\
\text { Abdurrahman } \\
\text { Wahid }\end{array}$} & $\begin{array}{l}\text { Nov 18, } \\
1999\end{array}$ & $\begin{array}{l}\text { Dissolution of the Ministry of } \\
\text { Social Affairs and the Ministry } \\
\text { of Education }\end{array}$ & $\begin{array}{l}\text { All fractions except } \\
\text { F-KB }\end{array}$ & Received \\
\hline & \begin{tabular}{|l} 
July 20, \\
2000
\end{tabular} & $\begin{array}{l}\text { Removal of Hamzah Haz and } \\
\text { Laksamana Sukardi }\end{array}$ & $\begin{array}{l}\text { All fractions except } \\
\text { F-KB }\end{array}$ & Received \\
\hline \multirow[t]{3}{*}{$\begin{array}{l}\text { President } \\
\text { Megawati } \\
\text { Sukarnoputri }\end{array}$} & $\begin{array}{l}\text { May 24, } \\
2002\end{array}$ & $\begin{array}{l}\text { Presidential assistance for the } \\
\text { construction of dormitories } \\
\text { for the Indonesian National } \\
\text { Army/Police of the Republic } \\
\text { of Indonesia }\end{array}$ & $\begin{array}{l}\text { All factions except } \\
\text { F-PDIP \& F-TNI/ } \\
\text { Polri: } 48 \text { people }\end{array}$ & $\begin{array}{l}\text { It did not } \\
\text { continue } \\
\text { because } \\
\text { Golkar did } \\
\text { not support } \\
\text { it }\end{array}$ \\
\hline & \begin{tabular}{|l} 
Early \\
June \\
2002
\end{tabular} & $\begin{array}{l}\text { President Megawati's visit } \\
\text { to Timor Leste attended the } \\
\text { invitation of President Xanana } \\
\text { Gusmao }\end{array}$ & $\begin{array}{l}\text { All factions except } \\
\text { F-PPP and F-TNI/ } \\
\text { Polri: } 25 \text { people }\end{array}$ & $\begin{array}{l}\text { Does not } \\
\text { continue }\end{array}$ \\
\hline & \begin{tabular}{|l|} 
June 24, \\
2003 \\
\end{tabular} & $\begin{array}{l}\text { The release of Sipadan and } \\
\text { Ligitan Islands } \\
\end{array}$ & \begin{tabular}{|l|} 
All fraction except \\
PDIP
\end{tabular} & Received \\
\hline \multirow{3}{*}{$\begin{array}{l}\text { President } \\
\text { Susilo } \\
\text { Bambang } \\
\text { Yudhoyono }\end{array}$} & Nov, 2004 & $\begin{array}{l}\text { The Helsinki MoU on the } \\
\text { Settlement of the Aceh Case }\end{array}$ & $\begin{array}{l}\text { F-PG, F-PDIP; F-KB: } \\
\text { F-PBR; F-PDS; F-PAN: } \\
55 \text { people }\end{array}$ & $\begin{array}{l}\text { Does not } \\
\text { continue }\end{array}$ \\
\hline & $\begin{array}{l}\text { Early Feb, } \\
2005\end{array}$ & $\begin{array}{l}\text { Selwapres letter regarding the } \\
\text { direction of the vice president } \\
\text { so that the minister does not } \\
\text { consider the importance of } \\
\text { the meeting with the House of } \\
\text { Representatives }\end{array}$ & $\begin{array}{l}\text { All factions except } \\
\text { F-PG and F-PD: } 19 \\
\text { people }\end{array}$ & $\begin{array}{l}\text { Does not } \\
\text { continue }\end{array}$ \\
\hline & $\begin{array}{l}\text { Feb 8, } \\
2005\end{array}$ & $\begin{array}{l}\text { Withdrawal of President } \\
\text { Megawati's letter regarding } \\
\text { the replacement of the TNI } \\
\text { Commander }\end{array}$ & $\begin{array}{l}\text { F-PDIP: F-KB: F-DS: } \\
49 \text { people }\end{array}$ & Rejected \\
\hline
\end{tabular}


Aulia, N. A., Husen, L. O., \& Gadjong, A. A., The Presidential System with ...

\begin{tabular}{c|l|l|l|l}
\hline \hline Period & \multicolumn{1}{|c|}{ Date } & \multicolumn{1}{|c|}{ Interpellation Material } & Proposer Elements & \multicolumn{1}{|c}{$\begin{array}{c}\text { Proposal } \\
\text { Status }\end{array}$} \\
\hline \hline \multirow{5}{*}{} & Sep, 2005 & $\begin{array}{l}\text { Teleconference Presidents of } \\
\text { the United States }\end{array}$ & $\begin{array}{l}\text { Cross factions: 20 } \\
\text { people }\end{array}$ & $\begin{array}{l}\text { Does not } \\
\text { continue }\end{array}$ \\
\cline { 2 - 5 } & $\begin{array}{l}\text { Sep 13, } \\
2005\end{array}$ & Hunger swelling and polio & $\begin{array}{l}\text { All factions except } \\
\text { F-PD }\end{array}$ & Received \\
\cline { 2 - 5 } & $\begin{array}{l}\text { Oct 17, } \\
2005\end{array}$ & Rise in fuel prices & F-PDIP, F-KB & Rejected \\
\cline { 2 - 5 } & $\begin{array}{l}\text { Jan 24, } \\
2006\end{array}$ & Rice Imports (1) & $\begin{array}{l}\text { F-PP, F-KB, F-PAN, } \\
\text { F-PDS }\end{array}$ & Rejected \\
\cline { 2 - 5 } & $\begin{array}{l}\text { Oct 17, } \\
2006\end{array}$ & Rice Imports (2) & F-PDIP & Rejected \\
\cline { 2 - 5 } & $\begin{array}{l}\text { June 5th, } \\
2007\end{array}$ & $\begin{array}{l}\text { Government support for the } \\
\text { UN Resolution on the Iran } \\
\text { nuclear issue }\end{array}$ & $\begin{array}{l}\text { All factions except } \\
\text { F-PD: 280 people }\end{array}$ & Received \\
\cline { 2 - 5 } & $\begin{array}{l}\text { June 17, } \\
2007\end{array}$ & Lapindo mudflow in Sidoarjo & $\begin{array}{l}\text { All factions except } \\
\text { F-PD: 153 people }\end{array}$ & Be Delayed \\
\cline { 2 - 5 } & Feb, 2008 & KLBI/BLBI case settlement & All factions & Received \\
\hline $\begin{array}{l}\text { President } \\
\text { Joko Widodo }\end{array}$ & Nov, 2014 & Rise in fuel prices & $\begin{array}{l}\text { Does not } \\
\text { continue }\end{array}$ \\
\cline { 2 - 5 } & Jan, 2015 & $\begin{array}{l}\text { The cancellation of the } \\
\text { appointment of Komjen Budi } \\
\text { Gunawan as the National } \\
\text { Police Chief }\end{array}$ & $\begin{array}{l}\text { Does not } \\
\text { continue }\end{array}$ & \\
\hline \hline
\end{tabular}

Source: Compiled from various sources

Table 2. The Proposed Use of the House of Representatives Inquiry Rights (19992019)

\begin{tabular}{|c|c|c|c|c|}
\hline Period & Date & Interpellation Material & Proposer Elements & $\begin{array}{l}\text { Proposal } \\
\text { Status }\end{array}$ \\
\hline \multirow[t]{2}{*}{\begin{tabular}{l|} 
President \\
Abdurrahman \\
Wahid
\end{tabular}} & $\begin{array}{l}\text { Augt 28, } \\
2000\end{array}$ & $\begin{array}{l}\text { Dana Yanatera Bulog and the } \\
\text { Sultan of Brunei (Buloggate } \\
\text { and Brunelgate) }\end{array}$ & $\begin{array}{l}\text { All factions except } \\
\text { F-KB and F-PDKB }\end{array}$ & Received \\
\hline & $\begin{array}{l}\text { Augt 28, } \\
2000\end{array}$ & $\begin{array}{l}\text { Bulog's non-budgetary funds } \\
\text { (Akbar Tandjung case) }\end{array}$ & $\begin{array}{l}\text { F-KB, F-PDIP, } \\
\text { F-PDKB, F-KKI }\end{array}$ & Rejected \\
\hline $\begin{array}{l}\text { President } \\
\text { Megawati } \\
\text { Sukarnoputri }\end{array}$ & Jan, 2003 & Divestment of PT Indosat & $\begin{array}{l}\text { F-Reformasi; F-KB; } \\
\text { F-PDU; } 137 \text { people }\end{array}$ & $\begin{array}{l}\text { Does not } \\
\text { continue }\end{array}$ \\
\hline \multirow{6}{*}{$\begin{array}{l}\text { President } \\
\text { Susilo } \\
\text { Bambang } \\
\text { Yudhoyono }\end{array}$} & $\begin{array}{l}\text { May 31, } \\
2005\end{array}$ & Rise in fuel prices & F-PDIP, F-KB, F-PDS & Rejected \\
\hline & $\begin{array}{l}\text { May 31, } \\
2005\end{array}$ & Illegal sugar auction & F-PDIP, F-KB, F-PDS & Rejected \\
\hline & $\begin{array}{l}\text { June 7, } \\
2005\end{array}$ & Pertamina tanker sales & All Factions & Received \\
\hline & $\begin{array}{l}\text { Jan 17, } \\
2006\end{array}$ & Bank Mandiri bad credit & $\begin{array}{l}\text { F-PDIP, others } \\
\text { withdrew }\end{array}$ & $\begin{array}{l}\text { Does not } \\
\text { continue }\end{array}$ \\
\hline & $\begin{array}{l}\operatorname{Jan} 24 \\
2006\end{array}$ & Rice Imports & \begin{tabular}{|l|} 
F-PDIP, F-PKS, F-PAN, \\
F-PDS
\end{tabular} & Rejected \\
\hline & $\begin{array}{l}\text { May 30, } \\
2006\end{array}$ & Cepu Block Management & Rejected & Rejected \\
\hline
\end{tabular}




\begin{tabular}{c|c|l|c|c}
\hline \hline Period & Date & Interpellation Material & Proposer Elements & $\begin{array}{c}\text { Proposal } \\
\text { Status }\end{array}$ \\
\hline \hline $\begin{array}{l}\text { President } \\
\text { Joko Widodo }\end{array}$ & Dec, 2009 & Century Bank scandal & & Received \\
\cline { 2 - 5 } & $\begin{array}{l}\text { March, } \\
2015\end{array}$ & $\begin{array}{l}\text { Yasonna Laoly's Ministry of } \\
\text { Law and Human Rights policy } \\
\text { regarding the turmoil at } \\
\text { Golkar }\end{array}$ & & $\begin{array}{l}\text { Does not } \\
\text { continue }\end{array}$ \\
\hline \hline
\end{tabular}

Source: Compiled from various sources

Based on the table above, the tendency of conflict and political tensions in the President-House of Representative's relationship was characterised mainly by President Susilo Bambang Yudhoyono's era. Since the era of President Abdurrahman Wahid to President Joko Widodo today, there are about 18 proposals (table 1) for the use of the right of interpellation, including: 2 proposals in the era of President Abdurrahman Wahid; 3 proposals during the era of President Megawati Soekarnoputri; 11 proposals in the era of President Susilo Bambang Yudhoyono; and 2 proposals during the era of President Joko Widodo. Meanwhile, the use of the House of Representatives inquiry right since the era of President Abdurrahman Wahid to President Joko Widodo today, there are about 11 proposals (table 2) for the use of the right to the inquiry, including 2 proposals in the era of President Abdurrahman Wahid; 1 proposal during the era of President Megawati Soekarnoputri; 6 proposals in the Susilo Bambang Yudhoyono era; and 2 proposals during the era of President Joko Widodo (Husen, L. O., 2019).

The presidential system, accompanied by extreme multiparty conditions in Indonesia, has resulted in a minority and divided government, which requires the elected President to make political compromises in parliament to support the effectiveness of the running of the government (Rantau, M. I., 2019). Besides, applying a multiparty system in the presidential government system weakens the presidential system and has implications for executive and legislative relations. The implications, namely; First, are the interests of political parties that conflict with government policies. Second, there is no permanent coalition arrangement. Third, the weak position of the President (Arman, Z., 2018). the coalition of Indonesian political parties in the presidential system illustrates that the President's power can be co-opted or limited due to political compromises between political parties and the President, who are members of the government coalition. The coalition formed by the government (the President and the supporting parties) is divided based on the composition of seats in the parliament and party support during the Presidential Election. It has an impact on the composition of the number of ministers in the government cabinet (Wospakrik, D., 2016).

In this regard, there are several ways to avoid this President and Vice-President conflict in the future (Haris, S., 2006). First, the restructuring of the President and the Vice-President relationship through the Presidential Institution Law, whose 
initial draft had been in the House of Representatives since the reign of President B. J. Habibie. The President's constitutional mandate is "assisted" by the VicePresident needs to be translated into law so that it becomes clearer what the VicePresident's powers are in assisting the President.

Second, the President and the Vice-President pair's nomination can only be carried out by significant parties or a permanent and/or semi-permanent coalition of parties in the House of Representatives. ${ }^{3}$ This second option must be done even though it is less democratic and unpopular because it closes opportunities for small parties with potential candidates.

Third, the President and the Vice-President candidate pair supported by a sizeable permanent coalition should come from the same party or political base so that disharmony or conflict and political tensions between the two can be minimized (Indrayana, D., 2006).

As a logical consequence of strengthening presidential democracy, checks and balances in the executive-legislative power relations in particular and the executivelegislative-judicial triangular relations tend to be increasingly institutionalized. However, it should be noted immediately that all the achievements of this institutional arrangement are still procedural-constitutional, whose substance is only fulfilled when it is reflected in political reality.

\section{The Presidential System with a Multiparty System Realizes a Stable and Dynamic Government}

The presidential or presidential government system or "non-parliamentary executive system" or "fixed executive system", which is accompanied by direct elections, will strengthen the President's position in dealing with the legislature. During his term of office, the President as a chief executive cannot be overthrown politically from his position. The characteristics of the presidential government system are as follows (Martosoewignyo, S. S., 2014):

1. The government system is based on the principle of separation of powers which refers to the Trias Politica theory. Executive power as executor of laws and regulations. Legislative power as a lawmaker as well as checks and balances for the executive. Judicial power as a supervisor for implementing laws and regulations with all the consequences. Thus, each of these powers independently cannot influence each other and performs its function following laws and regulations.

2. There is no mutual accountability between the chief executive (President) and cabinet members (Ministers). As an assistant to the President, the Minister is

${ }^{3}$ What is meant by a permanent and/or semi-permanent coalition is a coalition of parties committed to maintaining political support for the government if it is a coalition of parties supporting the government. One of the institutional mechanisms that can be designed is to tie a coalition or political agreement to a notary public and announce it by the General Election Commission. 
fully responsible to the President. In this case, it avoids the Ministers being accountable to the chairperson of their political party. It means avoiding the existence of twin suns, thus placing the Ministers as assistants to the President and fully responsible to the President.

3. The President cannot dissolve the legislative body (Parliament/Congress) and vice versa. The President does not have to resign (stop) if he does not get majority support from the legislature (Parliament/Congress). The President has a term of office of five years. The President cannot be overthrown, except through impeachment. The President has violated the law in treason against the state, corruption, bribery of other serious crimes or other despicable acts. The impeachment process goes through the process of proving the action at the Constitutional Court..

4. The presidential system of government is also called a fixed executive system. The President has a fixed term for five years. Furthermore, the people in a general election directly elect the President. Consequently, the President is not accountable to any agency and is only responsible to the people. The dismissal of the President can be carried out constitutionally through impeachment.

Thus the balance in the relationship between the President and the Parliament depends on the power possessed by the President that is owned by three sources, namely:

1. The power mentioned in the constitution;

2. The power of the parties supporting the President in Parliament; and

3. The legitimacy power in the general election, the President is elected directly by the people.

Presidential democracy with a "parliamentary taste", as we have seen, colours the relationship between the President and the House of Representatives in the form of a conflicted relationship with the instruments of using the right of interpellation, the right of inquiry, and the right of expression which then implies an ineffective government. On the other hand, so that the running of the government is not disturbed, the President often conducts consultations with the House of Representatives. The consultation mechanism between the President and the House of Representatives will lead to transactional politics.

Efforts to realize an effective presidential democracy must eliminate presidential democracy with a parliamentary taste. Presumably, it is necessary to restructure the constitutional design by giving adequate authority to the President in carrying out his duties as head of government and head of state. Some powers that should not belong to the legislative domain must be returned to the executive. The rights which should be exercised in the context of mechanism checks and balances are not intended to overthrow the President. 
Departing from the reality of presidential applied in Indonesia, as mentioned above, the multiparty extremes (a large number of parties) need to be pushed to become simple multi parties, especially the number of parliaments. There are three designs of political institutions that need to be designed and reorganized, namely (R., H. Y. A., 2010):

1. The design of elections needs to be designed to encourage the simplification of the number of political parties in parliament while at the same time, supporting the strengthening of the presidential government system. By reforming the electoral system, simplifying the number of political parties can be pursued through several institutional engineering agendas, namely:

a. implementing a district electoral system (plurality/majority system) or a mixed system (mixed-member proportional);

b. reducing the size of the electoral district (district magnitude);

c. consistently implementing the seat threshold in parliament (parliamentary threshold).

2. The design of parliamentary institutions aims to simplify the polarization of political power in parliament, such as reducing the number of factions and the effectiveness of coalitions so that the political process in parliament becomes more straightforward and more efficient. Besides, as a proportional and balanced examination framework to avoid a legislative body that is too strong.

3. The design of the presidential institution is also directed at strengthening the President's political position before the parliament so that parliamentary power is not above the President, but also avoids being too strong the President's position. It is also directed towards a solid cabinet, and the government can run effectively.

Therefore, there are several agendas for institutional engineering, including:

1. Rearranging the legislative system;

2. The President does not have the power to form laws but is given veto power;

3. Clarity of the powers of the Vice-President and the relationship between the President and the Vice-President; and

4. Rules are prohibiting concurrent positions for members of the cabinet.

\section{CONCLUSIONS AND SUGGESTIONS}

Based on the description of the results and discussion, it can be concluded that the implementation of the presidential system with a multiparty system, it is rare for a President to be elected and from the majority party. Furthermore, with the election of a minority President and a majority in Parliament, the President will strengthen his position by forming a coalition. However, building a stable coalition is difficult in a multiparty presidential democracy. The reason is that the coalition built has no legal attachment so that political parties can dissolve the coalition in the presidential 
system. The President's dilemma becomes more complex if no single party controls the majority of seats in Parliament. In addition to the polarization of parliamentary power, the President who comes from a small party or a coalition of minority parties also has the opportunity to become an essential factor for the stability and effectiveness of presidential democracy. On the one hand, the presidential election is based on the majority of "winners take all". On the other hand, the election for members of Parliament is carried out with a proportional system. Gunther, R. (2001) stated that mutual claims of legitimacy that cause conflict and tension between the President and Parliament have the opportunity to arise if there is no institutional mechanism that changes conflictual behavior to consensus in presidential-parliamentary relations. In this regard, the institutional engineering agenda that needs to be designed includes simplifying the number of factions in Parliament by tightening the threshold requirements for fraction formation; parliamentary coalition regulations aimed at both political blocs (coalition and opposition); strengthening the institution and authority of the Regional Representative Council to balance the House of Representatives so that the function of checks and balances does not only occur between the President and the House of Representatives but also between the House of Representatives and the Regional Representative Council. Besides, the draft presidential body is also directed at strengthening the President's political position before the Parliament so that the power of Parliament is not above the President and avoids seizing the President's position. Furthermore, the cabinet is also directed to a strong position so that the government can run effectively.

\section{REFERENCES}

The 1945 Constitution of the Republic of Indonesia.

The 1949 Provisional Constitution of the Republic of the United States of Indonesia.

The 1950 Provisional Constitution of the Republic of Indonesia.

Abdillah, M. (1999). Demokrasi di Persimpangan Makna: Respons Intelektual Muslim Indonesia terhadap Demokrasi (1966 - 1993). Yogyakarta: Tiara Wacana.

Arman, Z. (2018). Tinjauan Terhadap Sistem Multi Partai dalam Sistem Pemerintahan Presidensial di Indonesia pada Era Reformasi. Jurnal Cahaya Keadilan, Universitas Putera Batam, 6(1), pp. 22-39. doi: https://doi.org/10.33884/jck.v6i1.875

Asshiddiqie, J. (2001). Pengantar Pemikiran tentang Rancangan Perubahan UndangUndang Dasar Negara Kesatuan Republik Indonesia. Jakarta: The Habibie Center.

Asshiddiqie, J. (2003). Konsolidasi Naskah UUD 1945 Setelah Perubahan Keempat. Jakarta: PT. Yarsif Watampone.

Azhary, M. T. (2009). Negara Hukum: Suatu Studi tentang Prinsip-Prinsipnya Dilihat dari Segi Hukum Islam, Implementasinya pada Periode Negara Madinah dan Masa Kini. Jakarta: Kencana Prenada Media Group. 
Bachmid, F. (2021). Eksistensi Kedaulatan Rakyat dan Implementasi Parliamentary Threshold dalam Sistem Pemilihan Umum di Indonesia. SIGn Jurnal Hukum, CV. Social Politic Genius (SIGn), 2(2), pp. 87-103. doi: https://doi.org/10.37276/sjh. v2i2.83

Cheibub, J. A. (2002). Minority Government, Deadlock Situation, and the Survival of Presidential Democracies. Comparative Political Studies, 35(3), pp. 284-312.

D., M. M. M. (2000). Demokrasi dan Konstitusi di Indonesia: Studi tentang Interaksi Politik dan Kehidupan Ketatanegaraan. Jakarta: PT. Rineka Cipta.

D., M. M. M. (2010). Perdebatan Hukum Tata Negara: Pasca Amandemen Konstitusi. Jakarta: PT. Raja Grafindo Persada.

Efriza, E. (2018). Koalisi dan Pengelolaan Koalisi pada Pemerintahan Joko WidodoJusuf Kalla. Populis: Jurnal Sosial dan Humaniora, Universitas Nasional, 3(6), pp. 733-750. doi: http://dx.doi.org/10.47313/ppl.v3i6.470

Fitrah, F. A. (2021). Perbandingan Hukum terkait Pembentukan Pasal Penghinaan terhadap Peradilan, Perzinahan, dan Santet dalam RKUHP Indonesia. SIGn Jurnal Hukum, CV. Social Politic Genius (SIGn), 2(2), pp. 122-137. doi: https://doi. org/10.37276/sjh.v2i2.93

Gove, P. B. (Ed.) (1993). Webster's Third New International Dictionary. Massachusetts: Merriam-Webster, Inc.

Gunther, R. (2001). Membuka Dialog Mengenai Pilihan Institusional di Indonesia. In Bhakti, I. N. \& Sihbudi, R. (Eds.), Menjauhi Demokrasi Kaum Penjahat: Belajar dari Kekeliruan Negara-Negara Lain. Bandung: Mizan Pustaka in collaboration with LIPI and the Ford Foundation.

Hadjon, P. M. (1998). Perlindungan Hukum Bagi Rakyat di Indonesia: Sebuah Studi tentang Prinsip-Prinsipnya, Penanganannya oleh Peradilan dalam Lingkungan Peradilan Umum dan Pembentukan Peradilan Administrasi Negara. Surabaya: PT. Bina Ilmu.

Hamudy, M. I. A. \& Rifki, M. S. (2019). Strengthening the Multi-Party Presidential Government in Indonesia. Politik Indonesia: Indonesian Political Science Review, Universitas Negeri Semarang, 4(2), pp. 208-232. doi: https://doi.org/10.15294/ ipsr.v4i2.18447

Handayani, Y. (2014). Hak Mantan Narapidana sebagai Pejabat Publik dalam Perspektif Hak Asasi Manusia. Rechts Vinding Online, Kementerian Hukum dan Hak Asasi Manusia RI, 3, pp. 1-5.

Haris, S. (2006, 8 November). Disharmoni Yudhoyono - Kalla. Kompas.

Husen, L. O. (2005). Hubungan Fungsi Pengawasan Dewan Perwakilan Rakyat dengan Badan Pemeriksa Keuangan dalam Sistem Ketatanegaraan Indonesia. Bandung: CV. Utomo.

Husen, L. O. (2019). Negara Hukum, Demokrasi dan Pemisahan Kekuasaan. Makassar: CV. Social Politic Genius (SIGn). 
Indrayana, D. (2006, December 13). Mendesain Presidensial yang Efektif: Bukan Presiden 'Sial' atau Presiden 'Sialan'. Paper presented in Seminar, organized by DPP Partai Demokrat and Forum Komunikasi Partai Politik dan Politisi untuk Reformasi, in collaboration with Friedrich Naumann Stifftung (FNS), at Hotel Acasia, Jakarta.

Jennings, S. W. I. (1963). The Law and the Constitution (5 ed.). London: University of London Press.

Law of the Republic of Indonesia Number 2 of 2008 on the Political Party. (State Gazette of the Republic of Indonesia of 2008 Number 2, Supplement to the State Gazette of the Republic of Indonesia Number 4801).

Librayanto, R. (2009). Ilmu Negara: Suatu Pengantar. Makassar: Pustaka Refleksi.

Linz, J. J. (1994). Presidential or Parliamentary Democracy: Does it Make a Difference? In Linz, J. J. \& Valenzuela, A. (Eds.), The Failure of Presidential Democracy: Comparative Perspectives (Vol. 1, pp. 3-87). Baltimore: Johns Hopkins University Press.

Locke, J. (1967). Two Treatises of Government. New York: Cambridge University Press.

Mainwaring, S. (1993). Presidentialism, Multipartism, and Democracy: The Difficult Combination. Comparative Political Studies, 26(2), pp. 198-228.

Malian, S. (2001). Gagasan Perlunya Konstitusi Baru Pengganti UUD 1945. Yogyakarta: UII Press.

Marshall, G. (1971). Constitutional Theory. London: Oxford University Press.

Martosoewignyo, S. S. (2014). Hukum Tata Negara Indonesia: Pemikiran dan Pandangan. Bandung: PT. Remaja Rosdakarya.

Mayo, H. B. (1960). An Introduction to Democratic Theory. New York: Oxford University Press.

Montesquieu, B. d. (2011). The Spirit of Laws: Dasar-Dasar Ilmu Hukum dan Ilmu Politik (Anam, M. K., Trans.). Bandung: Nusamedia.

Notohamidjojo, O. (1970). Makna Negara Hukum bagi Pembaharuan Negara dan Wibawa Hukum bagi Pembaharuan Masyarakat di Indonesia. Jakarta: BPK Gunung Mulia.

Partono, P. (2008). Sistem Multipartai, Presidensial dan Persoalan Efektivitas Pemerintah. Jurnal Legislasi Indonesia, Kementerian Hukum dan Hak Asasi Manusia RI, 5(1), pp. 13-27.

Puspa, Y. P. (1997). Kamus Hukum: Bahasa Belanda, Indonesia, Inggris. Semarang: CV. Aneka Ilmu.

Qamar, N. \& Rezah, F. S. (2020). Metode Penelitian Hukum: Doktrinal dan Non-Doktrinal. Makassar: CV. Social Politic Genius (SIGn).

R., H. Y. A. (2010). Presidensialisme Setengah Hati: Dari Dilema ke Kompromi. Jakarta: PT. Gramedia Pustaka Utama. 
Rantau, M. I. (2019). Penguatan Sistem Presidensialisme di Indonesia: Analisis Terhadap Undang-Undang No. 7 Tahun 2017 Tentang Pemilihan Umum. Pelita: Jurnal Penelitian dan Karya Ilmiah, Universitas Islam Syekh Yusuf, 19(2), pp. 181193. doi: https://doi.org/10.33592/pelita.Vol19.Iss2.120

Suhyana, F. A., Suseno, S., \& Ramli, T. S. (2021). Transaksi Ilegal Menggunakan Kartu ATM Milik Orang Lain. SIGn Jurnal Hukum, CV. Social Politic Genius (SIGn), 2(2), pp. 138-156. doi: https://doi.org/10.37276/sjh.v2i2.92

Suny, I. (1985). Pembagian Kekuasaan Negara. Jakarta: Aksara Baru.

Suny, I. (2000, March 24-26). Upaya Mewujudkan Demokrasi dalam Negara Kesatuan Republik Indonesia Pasca Proklamasi 17 Agustus 1945. Paper presented in Legal Seminar in the Context of Amendment to the 1945 Constitution, organized by BPMPR with Fakultas Hukum Universitas Indonesia, at Bandar Lampung.

Wibisono, Y. (2017). Anomali Praktik Sistem Pemerintahan Presidensial dan Multipartai di Awal Pemerintahan Jokowi Tahun 2014. Ilmu dan Budaya, Universitas Nasional, 40(55), pp. 6361-6384.

Wiyono, S., et al. (2020). The Effectiveness of Presidential Cabinet in a Multi-Party System in Indonesia. European Journal of Political Science Studies, 4(1), pp. 1425.

Wospakrik, D. (2016). Koalisi Partai Politik dalam Sistem Politik Presidensial di Indonesia. Papua Law Journal, Universitas Cenderawasih, 1(1), pp. 142-161. doi: https://doi.org/10.31957/plj.v1i1.585

Yafid, B. M. \& Muzakkir, A. K. (2020). The Role of the Supervision and Observation Judge on Guidance for Inmates. Sovereign: International Journal of Law, CV. Social Politic Genius (SIGn), 2(2), pp. 40-56. doi: https://doi.org/10.37276/sijl.v2i2.33

\footnotetext{
Aulia, N. A., Husen, L. O., \& Gadjong, A. A. (2021). The Presidential System with a Multiparty System is Based on the 1945 Constitution of the Republic of Indonesia. Sovereign: International Journal of Law, CV. Social Politic Genius (SIGn), 3(1), pp. 1-19. ' I doi: https://doi.org/10.37276/sijl.v3i1.34
} 